\title{
Article \\ Determination of Cover and Land Management Factors for Soil Loss Prediction in Cameron Highlands, Malaysia
}

\author{
Mohd Amirul Mahamud ${ }^{1}\left(\mathbb{D}\right.$, Noor Aida Saad ${ }^{2, *(\mathbb{C})}$, Roslan Zainal Abidin ${ }^{2}$, Mohd Fazly Yusof ${ }^{2}$, \\ Nor Azazi Zakaria ${ }^{2}$, Mohd Aminur Rashid Mohd Amiruddin Arumugam ${ }^{3}$, Safari Mat Desa ${ }^{3}$ \\ and Md. Nasir Md. Noh ${ }^{3}$ \\ 1 Geoinformatic Unit, Geography Section, School of Humanities, Universiti Sains Malaysia, \\ Minden 11800, Penang, Malaysia; mohd.amirul@usm.my \\ 2 River Engineering and Urban Drainage Research Centre, Engineering Campus, Universiti Sains Malaysia, \\ Nibong Tebal 14300, Penang, Malaysia; drroslan.za@gmail.com (R.Z.A.); redac07@usm.my (M.F.Y.); \\ redac01@usm.my (N.A.Z.) \\ 3 River Basin Research Centre, National Hydraulic Research Institute of Malaysia, \\ Seri Kembangan 43300, Selangor, Malaysia; rashid@nahrim.gov.my (M.A.R.M.A.A.); \\ safari@nahrim.gov.my (S.M.D.); nasirnoh@nahrim.gov.my (M.N.M.N.) \\ * Correspondence: aidasaad@usm.my; Tel.: +60-4-599-6538
}

check for updates

Citation: Mahamud, M.A.; Saad, N.A.; Zainal Abidin, R.; Yusof, M.F.; Zakaria, N.A.; Mohd Amiruddin Arumugam, M.A.R.; Mat Desa, S.; Md. Noh, M.N. Determination of Cover and Land Management Factors for Soil Loss Prediction in Cameron Highlands, Malaysia. Agriculture 2022, 12, 16. https://doi.org/10.3390/ agriculture12010016

Academic Editors: Othmane Merah, Purushothaman Chirakkuzhyil Abhilash, Magdi T. Abdelhamid, Hailin Zhang and Bachar Zebib

Received: 25 November 2021 Accepted: 21 December 2021 Published: 24 December 2021

Publisher's Note: MDPI stays neutral with regard to jurisdictional claims in published maps and institutional affiliations.

Copyright: (C) 2021 by the authors. Licensee MDPI, Basel, Switzerland. This article is an open access article distributed under the terms and conditions of the Creative Commons Attribution (CC BY) license (https:// creativecommons.org/licenses/by/ $4.0 /)$.

\begin{abstract}
Many new agricultural activities resulted in severe soil erosion across the Cameron Highlands' land surface. Therefore, this study determines the cover $(C)$ and land management $(P)$ factors of the USLE for predicting soil loss risk in Cameron Highlands using a Geographic Information System (GIS). For this study, data from the Department of Agriculture Malaysia (DOAM) and the Department of Town and Country Planning Malaysia (PLANMalaysia) were used to generate several $C \& P$ factors in the Cameron Highlands. Data from both agencies have resulted in $C$ factors with 0.01 to 1.00 and $P$ factors with 0.30 to 0.49 . Due to the cover and land management factor varies depending on the data collected by the various agencies, this study used the two data sets to come up with a CEP factor that accurately reflected both agricultural and urban growth effects. RKLS factors of USLE were obtained from the DOAM with values $R$ (2375-2875), K (0.005), LS (2.5-25), respectively. The Cameron Highlands' soil loss risk with these new CEP values resulted in a soil loss of 6.72 per cent ( 4547.22 hectares) from high to critical, with a percentage difference range of -0.77 to +3.37 under both agencies, respectively.
\end{abstract}

Keywords: cover management factor; land management factor; soil erosion; soil loss; soil risk; USLE

\section{Introduction}

Soil erosion is a key effect of land degradation worldwide and is described as removing too much soil by erosion agents [1,2]. The seven major categories of soil degradation are based on the source of deterioration: water erosion, wind erosion, mass motion, salt excess, and physical, biological, and chemical degradation [2]. Soil erosion has also become a worldwide issue due to population growth and continued land-clearing activities, particularly in developing and underdeveloped countries [3]. Soil erosion has put developing countries such as Malaysia in danger by causing the loss of rich topsoil, reducing water storage capacity and water quality, and increasing flood hazards [2]. Erosion and sedimentation problems are inevitable, as many places in Malaysia are undergoing dramatic changes, including land reclamation for housing, forestry, and agricultural estates [1-4]. Soil erosion research helps decision makers estimate the amount of soil loss in a specific location and propose alternative land management methods [4].

The terrain in Cameron Highlands has been uncovered and levelled for horticultural development, concentrated harvesting, and urban advancement for a long time [4,5]. A suitable area for horticulture is a location with inclination slopes of more than $25^{\circ}$ at an altitude of more than $500 \mathrm{~m}$ above sea level and if not effectively managed poses a high 
risk of erosion-induced landslide and soil erosion [4-6]. Agricultural inclusion is relatively limited in the Cameron Highlands, primarily on high slants [6]. The widespread use of organic manure and insecticides by local ranchers has resulted in noticeable levels of soil erosion and environmental pollution and an increase in the frequency of large tempest events [6,7]. Due to the wind, rivers, or both, several modern rural approaches have resulted in severe soil erosion $[1,2,7]$. As a result, this finding is crucial, and a much more accurate forecast of soil erosion risks should be developed for future planning.

Cropping and management actions on agricultural land have the largest direct effects on soil erosion [7]. Previous land use and current soil humidity can also affect the erodibility of the soil [8]. Terracing, sheltering, and contouring are common conservation practices in agricultural settings that reduce soil erosion considerably [6,9]. Through Good Agricultural and Environmental Condition (GAEC) measures, the European Union (EU) introduced ploughing and planting up and down the slope in hilly areas, as well as the maintenance of landscape features such as contouring, stone walls (and terraces), and buffer strips (grass margin) in hilly areas [10]. For all sub-factor practices, EU land management factors vary from 0.5251 to 0.9989 [10,11]. Improved land management factor values for farmlands with tillage measures (" $P$ " 0.53 ), grasslands with engineering measures (" $P$ " 0.23 ), woodlands with biological measures (" $P$ " 0.28 ), and other land-use types with biological measures (" $P$ " 0.51 ) were found in a study conducted in mountainous and hilly areas of Hubei province with data collected from 2000 to 2019 [12]. These are long-term investigations that do not change frequently. To better appreciate the impact of these behaviours, we must consider how water travels through a landscape [9-12].

However, assessing soil loss caused by water erosion at diverse spatiotemporal scales is difficult; as a result, erosion models are frequently used to calculate soil loss. Soil erosion models range from simple analytical models, such as the Universal Soil Loss Equation (USLE) and Erosion Productivity Impact Calculator (EPIC), to process-based models, such as the Soil and Water Assessment Tool (SWAT) model to calculate soil loss $[9,12,13]$. The SWAT model, similar to the USLE model, requires similar parameters and is commonly used to assess the impact of agricultural land management [14]. Mittelstet et al. [14] assessed conservation practices and management adjustments in the Eucha-Spavinaw watersheds to achieve numeric water-quality standards. The USLE model, on the other hand, is a simple and practical approach that was used in this work and is based on the DOAM's standard erosion plot study [15]. The USLE also allows for assessing the influence of these activities on soil erosion, and can be used to design a conservation plan for a given field [9].

The model calculates the mean soil loss yearly from sheet and flowing water erosion as a linear combination of five parameters: current/future rainfall erosivity $(R)$, soil erodibility $(K)$, slope length and steepness $(L S)$, cover management $(C)$, and land management $(P)$, as shown in Equation (1):

$$
A=R \times K \times L S \times C \times P
$$

The erosivity component of rainfall could considerably affect the stability of aggregate particles and increase soil loss [16,17]. It is a dynamic factor with a wide spatial and temporal variation range. Three Representative Concentration Pathways (RCPs) can be used to assess future rainfall erosivity values, ranging from its most aggressive mitigation pathway (RCP 2.6) to the least aggressive mitigation pathway (RCP 8.5) [16]. National-scale research based on average weather conditions can be used to identify areas with a shortage of rain gauge station data [17]. Following this, the RKLSCP features are given in the USLE model, which assesses and forecasts soil loss risk.

Combining the model with Geographic Information Systems (GIS) was proven in several investigations to yield consistent results [18,19]. Construction models can use GIS to build thematic maps from spatial information [18]. Geostatistical techniques are quickly used in soil research to explore the spatial variation of various soil parameters and spatially interpolate distributions of physical, chemical, and biological variables [19]. 
These methodologies were utilized to characterize and quantify spatial changes for rational interpolation and predict interpolated value variance using mean information [19].

According to Panos et al. [20], the tailored use of cover crops in soil erosion regions can partially or fully alleviate the effects of climate change on soil losses. The revised cover $(C)$ and land management $(P)$ values address a research gap left by previous findings from the Department of Agriculture Malaysia (DOAM) and the Department of Town and Country Planning Malaysia (PLANMalaysia). These cover and land management values will potentially provide further acceptable and specific soil loss concerns, allowing land-use activities to be monitored and planned by the responsible authorities. As a result, the proposed study goal is to develop $C$ (Cover Management) and $P$ (Land Management) values for predicting soil loss in Malaysia's Cameron Highlands.

\section{Study Area and Data}

\subsection{Study Area}

Cameron Highlands is a district of Pahang, Malaysia, with a land area of approximately $68,156.74$ ha. Figure 1 shows the location of Cameron Highlands. The elevation of the Cameron Highlands varies from $200 \mathrm{~m}$ to $2069.85 \mathrm{~m}$. A hilly environment borders the Cameron Highlands with steep slopes of more than 20 degrees [21,22]. According to the Department of Agriculture Malaysia, steep land and urban land are the two major soil types (generally can be termed as a typical land profile) in Cameron Highlands. It also has four recognized soil series: Teringkap series, Ringlet series, Tanah Rata series, and Gunong Berinchang series.

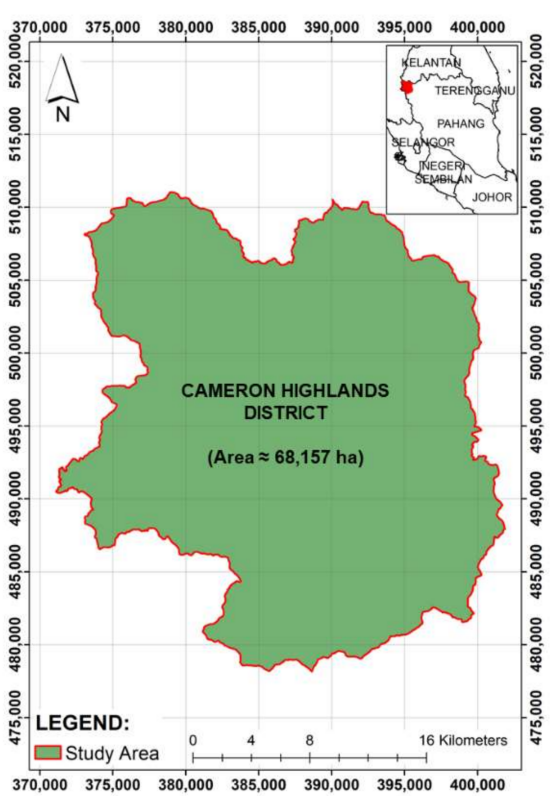

(a)

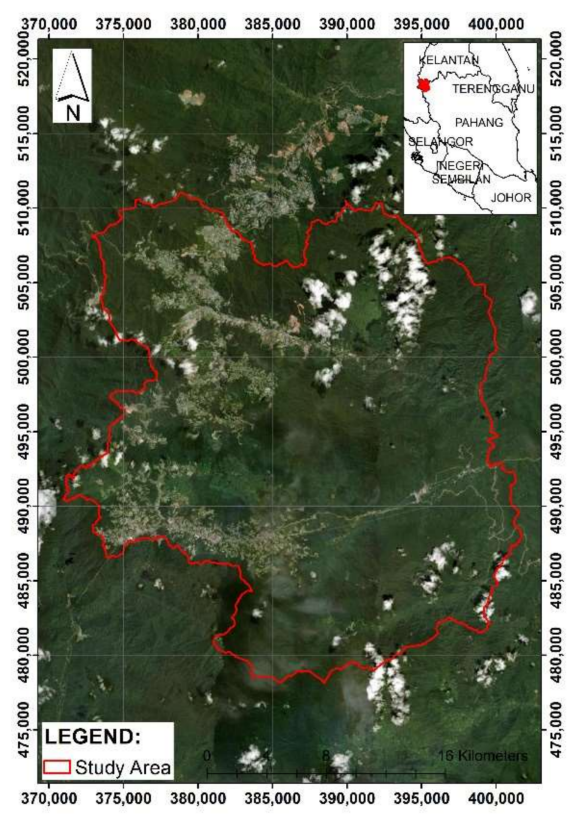

(b)

Figure 1. (a) District of Cameron Highlands as the study area (adapted from Ref. [21]), (b) view of the study area from Google Earth [23].

\subsection{Land Use Information}

The land use information is essential for evaluating and managing an area or region. Land use refers to the management and conversion of the environment or wilderness into developed ecosystems such as farmland, pastures, towns, the military, leisure, and transportation. The surface features of the catchment substantially impact the flow rate and other run-off parameters. Various activities can impact soil, resulting in problems such as flooding and landslides. Soil loss risk can be predicted and computed using land-use data to aid local planners and governments. 
Land-use statistics are available from the Department of Agriculture Malaysia for 2015 [21] and the Department of Town and Country Planning Malaysia for 2018 [24]. These two agencies produce different cover and land management values regarding agricultural and urban establishments. Figure $2 \mathrm{a}, \mathrm{b}$ presents the information of land use in Cameron Highlands (b). The most major land use in Cameron Highlands is forest, accounting for 91.85\% [21] and 87.88\% [24]. Table 1 presents the area of land use in Cameron Highlands. The main agricultural crops in Cameron Highlands are tea, vegetables, and decorative plants. For analysis and review, the data received from both agencies were utilized.

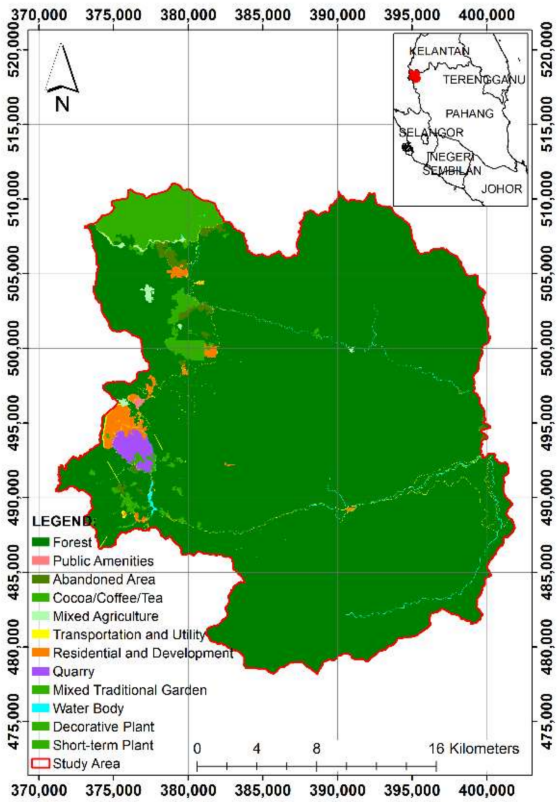

(a)

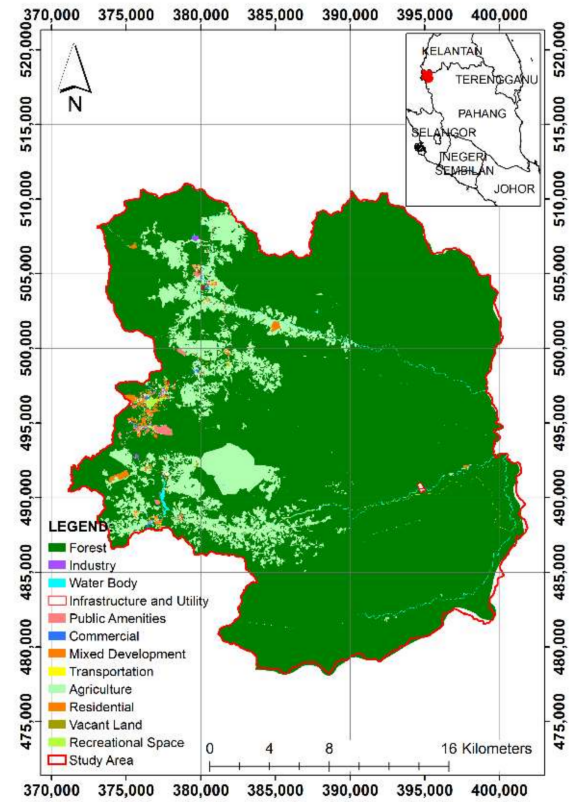

(b)

Figure 2. Land use information of the Cameron Highlands provided by (a) DOAM (adapted from Ref. [21]) and (b) PLANMalaysia (adapted from Ref. [24]).

Table 1. Details of land use activities in Cameron Highlands [21,24].

\begin{tabular}{|c|c|c|c|c|c|}
\hline \multicolumn{3}{|c|}{ DOAM (2015) } & \multicolumn{3}{|c|}{ PLANMalaysia (2018) } \\
\hline Land-Use & Area (ha) & Percentage & Land-Use & Area (ha) & Percentage \\
\hline Forest & $62,600.1306$ & 91.85 & Forest & $59,788.6463$ & 87.88 \\
\hline Water Body & 253.8581 & 0.37 & Water Body & 263.3853 & 0.39 \\
\hline Public Amenities & 34.6962 & 0.05 & Public Amenities & 162.8356 & 0.24 \\
\hline $\begin{array}{l}\text { Residential and } \\
\text { Development }\end{array}$ & 692.5808 & 1.02 & Residential & 351.8190 & 0.52 \\
\hline Quarry & 455.8169 & 0.67 & Industry & 20.9987 & 0.03 \\
\hline Transportation and Utility & 264.3966 & 0.39 & Infrastructure and Utility & 28.3891 & 0.04 \\
\hline Abandoned Area & 476.5986 & 0.70 & Transportation & 43.2753 & 0.06 \\
\hline Mixed Agriculture & 154.7226 & 0.23 & Commercial & 61.4781 & 0.09 \\
\hline Mixed Traditional Garden & 3.5818 & 0.01 & Mixed Development & 1.3571 & 0.00 \\
\hline Cocoa/Coffee/Tea & 201.5902 & 0.30 & Recreational Space & 57.6358 & 0.08 \\
\hline Decorative Plant & 79.2568 & 0.12 & Agriculture & 7212.9312 & 10.60 \\
\hline Short-Term Plant & 2939.5144 & 4.31 & Vacant Land & 43.2777 & 0.06 \\
\hline Total & $68,156.7436$ & 100.00 & Total & $68,156.7436$ & 100.00 \\
\hline
\end{tabular}




\section{Methods and Procedures}

\subsection{Methodology}

Collecting spatial data is critical in the early stages of establishing new cover and land management factors. The Department of Agriculture Malaysia [21], the Department of Town and Country Planning Malaysia [24], and the Department of Survey and Mapping Malaysia [22] were among the sources of spatial data. Spatial data were input into ArcGIS 10.4 , tabulated, and/or a graphical representation was generated for substantial study. Data collection for this study consisted of obtaining, combining, and cleaning up existing data from various sources. For ease of use and reference in the study's later stages, these data and information were packaged into an integrated database. Gaps and discrepancies were identified and addressed as necessary. To cover the gap or settle disagreements, extra data might be acquired through additional data collecting or field research.

Geospatial data such as the Digital Elevation Model (DEM), land use, and soil characteristics of the study region were the primary sources for the proposed research. Most government organizations created GIS databases to store geographical data in their possession. When primary data were not available, the research relied on alternative information, such as hardcopy maps from the DOAM and Landsat images, to fill in the gaps. Spatial data are one of the most crucial forms of information for any study or strategy, and they provide information on attribute variation across a location and this variation must be carefully monitored.

\subsection{New Cover and Land Management Factors}

Cover Management $(C)$ is one of the most important factors for reducing the rate of soil erosion in a particular place. The $C$ factors that include ground cover and plants are essential for reducing soil erosion at a building site or disturbing terrain. Table 2 shows the acceptable $C$ values for Cameron Highlands published by the Department of Irrigation and Drainage (DID) Malaysia based on Agricultural, Forested, Urbanized Areas and Undisturbed Land [15]. It is important to note that the proposed $C$ factor was based on typical values for ordinary run-off situations, and it should be utilized with caution. Thus, this study established the new $C$ factor by considering the published data from DID, DOAM and PLANMalaysia.

Land Management $(P)$ is another important factor that prevents soil erosion at a particular place. If erosion occurs, the $P$ factor is required to maintain silt and sediment from pouring away from the site in flowing water. Combining both C\&P factor methodologies makes it possible to limit sediment loading. Table 3 shows the acceptable $P$ values for Cameron Highlands published by the Department of Irrigation and Drainage (DID) Malaysia and based on BMPs for Construction/Developing Sites [15]. It is worth noting that the suggested $P$ factor is based on the usual values under average run-off conditions. As a result, it should be used with caution for various surface and run-off circumstances. Thus, this study also established the new $P$ factor by considering the published data from DID, DOAM and PLANMalaysia. 
Table 2. Cover Management, $C$ factor for Agricultural, Forested, Urbanized Areas and Undisturbed Land ${ }^{1}$ (adapted from Refs. [25-30]).

\begin{tabular}{cc}
\hline Cover Management & C Factor \\
\hline Quarrying Areas & 1.00 \\
Forest & \\
25\% Cover & 0.42 \\
$50 \%$ Cover & 0.39 \\
$75 \%$ Cover & 0.36 \\
100\% Cover & 0.03 \\
\hline Agricultural Areas & \\
Agricultural Plants & 0.38 \\
Cocoa/Tea/Coffee & 0.25 \\
Coconut/Oil Palm/Rubber & 0.20 \\
Paddy & 0.20 \\
Flower/Fruit & 0.01 \\
Urbanized Areas & 0.30 \\
Residential & \\
\hline Lorticulture/Traditional Mixed Plants & 0.25 \\
Medium Density (25\% Green Area) & 0.15 \\
High Density (5\% Green Area) & 0.05 \\
Commercial, Industrial and Educational & 0.25 \\
Low Density (50\% Green Area) & 0.15 \\
Medium Density (25\% Green Area) & 0.05 \\
High Density (5\% Green Area) & 0.01 \\
Impervious (Parking Lot, Road, etc.) & 0.01 \\
\hline Water Body &
\end{tabular}

${ }^{1}$ Average run-off condition.

Table 3. Land Management, $P$ Factor for BMPs for Construction/Developing Sites ${ }^{1}$ (adapted from Refs. [27-32]).

\begin{tabular}{|c|c|c|}
\hline \multicolumn{2}{|c|}{ Land Management } & $P$ Factor \\
\hline \multicolumn{2}{|c|}{ Bare Soil } & 1.00 \\
\hline \multicolumn{2}{|c|}{ Wired Log/Sandbag Barriers } & 0.85 \\
\hline \multicolumn{3}{|c|}{$\begin{array}{c}\text { Contour Furrowed Surface (Maximum Length Refers to } \\
\text { Downslope Length) }\end{array}$} \\
\hline Slope (\%) & Max. Length & \\
\hline 1 to 2 & 120 & 0.60 \\
\hline 3 to 5 & 90 & 0.50 \\
\hline 6 to 8 & 60 & 0.50 \\
\hline 9 to 12 & 40 & 0.60 \\
\hline 13 to 16 & 25 & 0.70 \\
\hline 17 to 20 & 20 & 0.80 \\
\hline$>20$ & 15 & 0.80 \\
\hline \multicolumn{3}{|c|}{ Terracing } \\
\hline \multicolumn{3}{|c|}{ Slope $(\%)$} \\
\hline \multicolumn{2}{|c|}{1 to 2} & 0.12 \\
\hline \multicolumn{2}{|c|}{3 to 8} & 0.10 \\
\hline \multicolumn{2}{|c|}{9 to 12} & 0.12 \\
\hline \multicolumn{2}{|c|}{13 to 16} & 0.14 \\
\hline \multicolumn{2}{|c|}{17 to 20} & 0.16 \\
\hline \multicolumn{2}{|c|}{$>20$} & 0.18 \\
\hline
\end{tabular}

\footnotetext{
${ }^{1}$ Average run-off condition.
} 


\section{Results and Discussion}

In Cameron Highlands, the RKLS and new CEP factors are incorporated into the USLE equation to predict soil loss. The $C$ factor is determined using the existing Cameron Highlands land use. The Department of Agriculture Malaysia and the Department of Town and Country Planning Malaysia are two separate sources of land-use data obtained for this study. Thus, this study established the $C$ factor by merging and averaging data from both agencies to determine the acceptable new $C$ factor and soil loss risk. The new $C$ factor determined and derived for the study is shown in Figure 3.

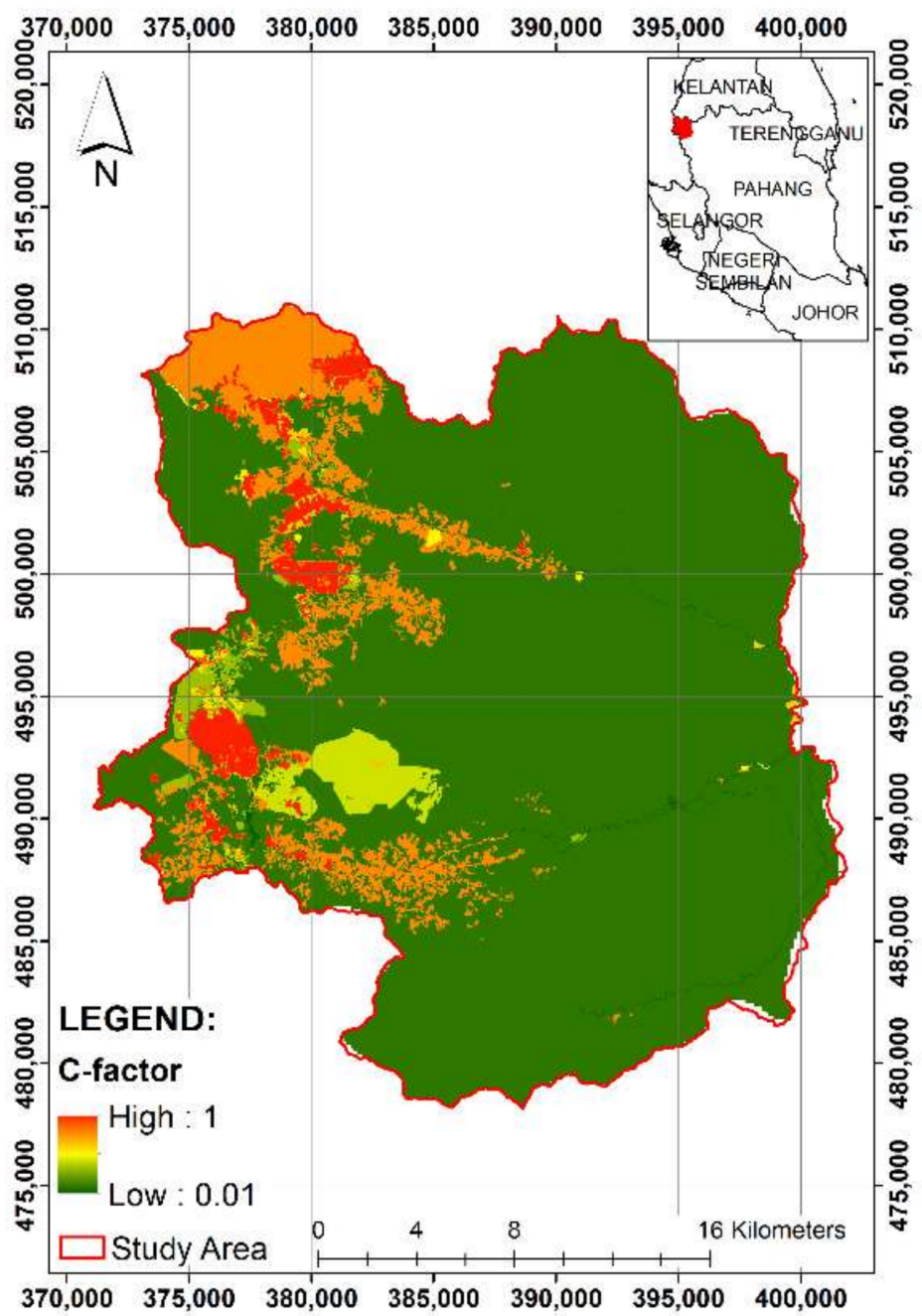

Figure 3. New $C$ factor in Cameron Highlands derived from the study [33].

The new $P$ factor is calculated by multiplying the existing conservation practice ratio comprising 27\% contouring, 15\% terracing, and 58\% sheltering with the corresponding $P$ values obtained from DOAM. This new $P$ factor for Cameron Highlands is shown in Figure 4.

A soil loss map for the Cameron Highlands district is created by implementing new CEP factors developed in the research. Soil loss was then analyzed and customized to the ecological conditions, including soil, terrain, land use, and their interactions. The probability of soil loss is calculated using the annual average soil loss suggested by Wischmeier and Smith [31] and Musgrave [34]. According to the research, 11.2 tons/ha/year is the maximum amount of soil loss that can be tolerated in any type of soil erosion condition. Based on this tolerable soil loss, the annual soil loss calculated was categorized accordingly, as shown in Table 4. 


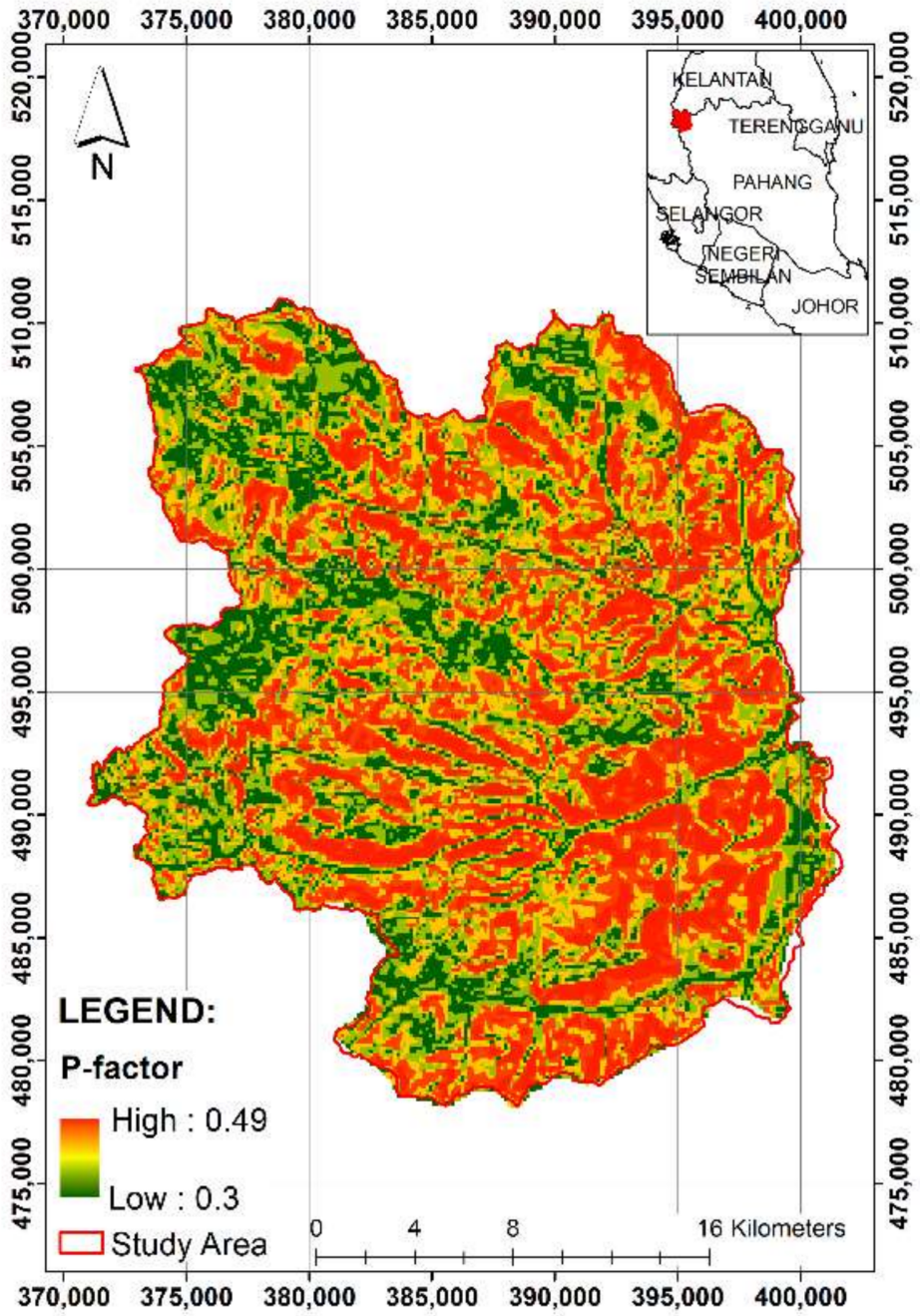

Figure 4. New $P$ factor in Cameron Highlands derived from the study [33].

Table 4. Establishment of soil loss class category adapted from this study [33].

\begin{tabular}{cc}
\hline $\begin{array}{c}\text { Soil Loss }(\boldsymbol{A}) \text {-Factor } \\
\text { (tons/ha/year) }\end{array}$ & Category \\
\hline$\leq 10$ & Low \\
$11-25$ & Moderate \\
$26-50$ & High \\
$51-100$ & Very High \\
$\geq 101$ & Critical \\
\hline
\end{tabular}

Figure 5 presents the soil loss map created from the new CEP factors developed in the research.

Table 5 shows the soil loss risk level area established using the new CEP factors.

Table 5. Soil loss risk, area and percentage in the Cameron Highlands [33].

\begin{tabular}{ccccc}
\hline District & $\begin{array}{c}\text { Soil Loss Class } \\
\text { Category }\end{array}$ & $\begin{array}{c}\text { Risk } \\
\text { (tons/ha/year) }\end{array}$ & Area (ha) & Percentage \\
\hline & Low & $\leq 10$ & $57,104.87$ & 84.37 \\
Cameron & Moderate & $11-25$ & 6034.52 & 8.92 \\
Highlands & High & $26-50$ & 3945.03 & 5.83 \\
& Very High & $51-100$ & 589.66 & 0.87 \\
& Critical & $\geq 101$ & 12.65 & 0.02 \\
\hline
\end{tabular}




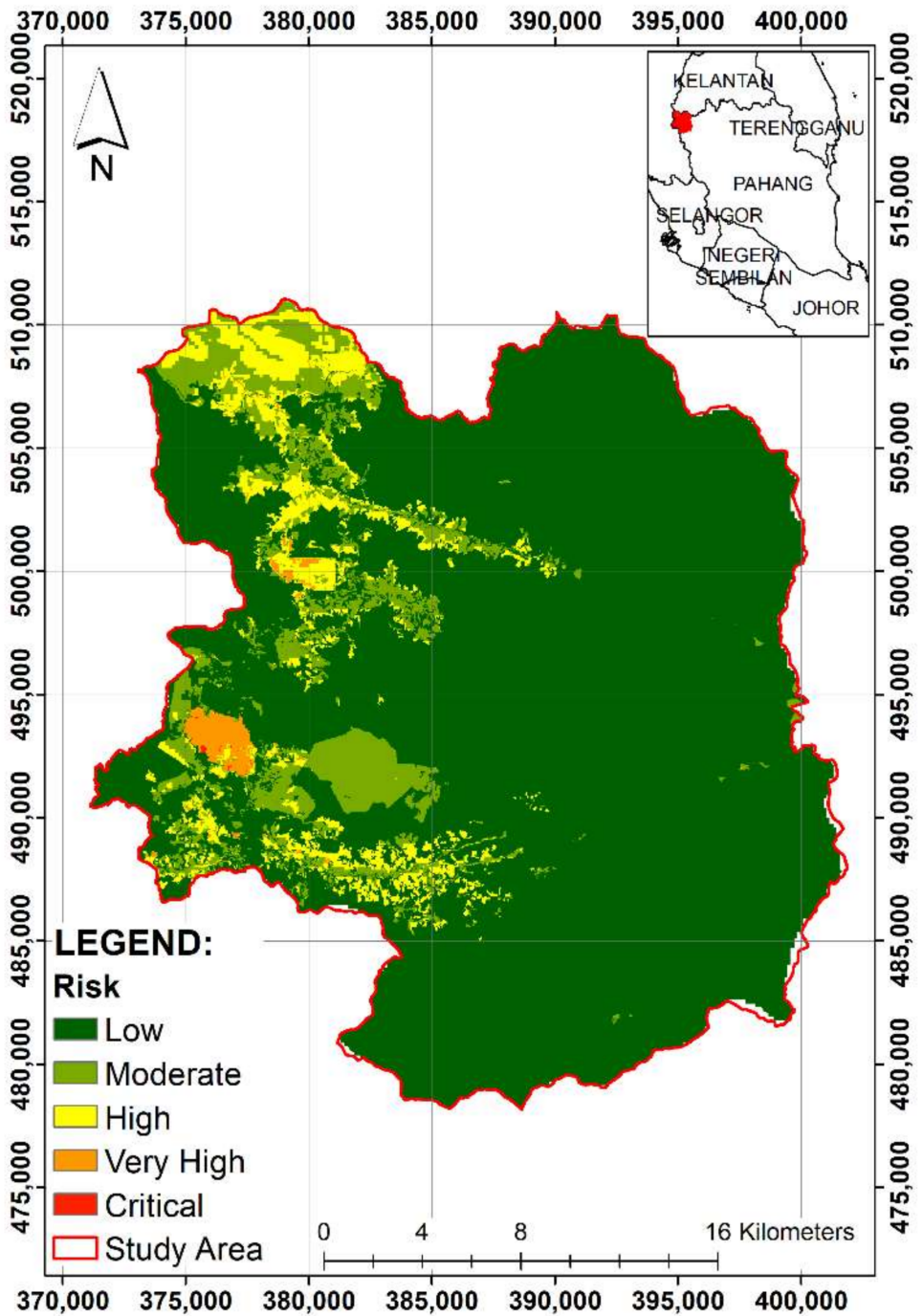

Figure 5. Annual average soil loss predicted in the study [33].

The existing situation of soil loss risk in Cameron Highlands district was quite compatible with the newly produced CEP factors and new soil loss risk based on the published soil loss risk levels and categories. Additionally, the new soil loss risk defined in the research was more thorough and followed the acceptable level of soil loss. Local governments can benefit from the findings of this research. However, they must consider these newly generated $C \mathcal{E} P$ factors and the soil loss risk with extra caution to avoid future erosion-induced landslides. Future research could be expanded by obtaining the most recent large data on land use and spatial planning in the study area from more relevant government bodies.

\section{Conclusions}

This research aimed to determine the new CEP components of the USLE in the Cameron Highlands under various cover and land management practices. The $C$ factor is adequate for capturing agricultural and urban development impacts using land use data from the Department of Agriculture Malaysia and the Department of Town and Country Planning Malaysia. The $P$ factor in Cameron Highlands' most recent conservation practices ratio also produces useful results that can assist with predicting soil loss risk in the area. The quarry site has the highest $C$ factor (1.00), whereas most of the forests in Cameron Highlands have the lowest $C$ factor (0.01). The study's $C$ factor, which measures agricultural and urban growth in Cameron Highlands, spans from 0.01 to 1.00; considering both data when computing the $C$ factor led to a more precise soil loss risk forecast. The conservation 
practice ratio in the Cameron Highlands is shown by the $P$ factor, which ranges from 0.30 to 0.49. According to the soil loss risk, $93.28 \%$ of the Cameron Highlands region $(63,119.74$ ha) faces a low-moderate soil loss, while $6.72 \%$ (4547.22 ha) faces high-critical soil loss. In the estimated high-critical soil loss risk area of Cameron Highlands, local governments can create extra restrictions and policies to prevent soil erosion. Determining the appropriate $C \mathcal{E P}$ factor values will reduce uncertainty in future research on predict soil loss in the Cameron Highlands.

Author Contributions: Conceptualization, N.A.S. and R.Z.A.; methodology, M.A.M., N.A.S. and M.F.Y.; software, M.A.M., M.A.R.M.A.A. and S.M.D.; validation, N.A.S., R.Z.A., N.A.Z. and S.M.D.; formal analysis, M.A.M., N.A.S. and M.F.Y.; investigation, R.Z.A., N.A.Z. and M.A.R.M.A.A.; resources, M.A.R.M.A.A., S.M.D. and M.N.M.N.; data curation, N.A.S., M.F.Y. and S.M.D.; writingoriginal draft preparation, M.A.M., N.A.S. and M.F.Y.; writing-review and editing, R.Z.A., N.A.Z. and M.A.R.M.A.A.; visualization, M.A.M., N.A.S. and M.F.Y.; supervision, R.Z.A. and N.A.Z.; project administration, N.A.S. and S.M.D.; funding acquisition, N.A.S., M.A.R.M.A.A., S.M.D. and M.N.M.N. All authors have read and agreed to the published version of the manuscript.

Funding: This research was funded by the National Hydraulic Research Institute of Malaysia (NAHRIM), grant number 304.PREDAC.6050430.I136 (Research on Preparation of Erosion and Sediment Control Plans (ESCP) Manual for logging and agriculture activities in Malaysia).

Institutional Review Board Statement: Not applicable.

Informed Consent Statement: Not applicable.

Data Availability Statement: The data presented in this study are available upon request from the corresponding author and respective Malaysian government agencies. The data are not publicly available due to Malaysian Government regulations which are strictly adhered.

Acknowledgments: The authors would like to thank the National Hydraulic Research Institute of Malaysia (NAHRIM) for the funding provided for the success of this research. We would also like to thank River Engineering and Urban Drainage Research Centre Universiti Sains Malaysia (REDAC USM) for supporting the research and Article Processing Charge (APC).

Conflicts of Interest: The authors declare no conflict of interest.

\section{References}

1. Parveen, R.; Kumar, U. Integrated Approach of Universal Soil Loss Equation (USLE) and Geographical Information System (GIS) for Soil Loss Risk Assessment in Upper South Koel Basin, Jharkhand. J. Geogr. Inf. Syst. 2012, 4, 588-596. [CrossRef]

2. Vijith, H.; Seling, L.W.; Dodge-Wan, D. Estimation of Soil Loss and Identification of Erosion Risk Zones in a Forested Region in Sarawak, Malaysia, Northern Borneo. Environ. Dev. Sustain. 2018, 20, 1365-1384. [CrossRef]

3. Samat, N.; Mahamud, M.A. Urbanisation in the George Town Conurbation and Its Impact to the Environment. Int. J. Environ. Eng. 2018, 9, 240-253. [CrossRef]

4. Noh, N.S.M.; Sidek, L.M.; Wayayok, A.; Abdullah, A.F.; Basri, H.; Farhan, S.A.; Sulaiman, T.; Md Ariffin, A.B. Erosion and Sediment Control Best Management Practices in Agricultural Farms for Effective Reservoir Sedimentation Management at Cameron Highlands. Int. J. Recent Technol. Eng. 2019, 8, 6025-6198.

5. Raj, J. Land Use Changes, Soil Erosion and Decreased Base Flow of Rivers at Cameron Highlands, Peninsular Malaysia. Bull. Geol. Soc. Malays. 2002, 45, 3-10. [CrossRef]

6. Razali, A.; Syed Ismail, S.N.; Awang, S.; Praveena, S.M.; Zainal Abidin, E. Land Use Change in Highland Area and Its Impact on River Water Quality: A Review of Case Studies in Malaysia. Ecol. Process 2018, 7, 19. [CrossRef]

7. Akale, A.T.; Dagnew, D.C.; Belete, M.A.; Tilahun, S.A.; Mekuria, W.; Steenhuis, T.S. Impact of Soil Depth and Topography on the Effectiveness of Conservation Practices on Discharge and Soil Loss in the Ethiopian Highlands. Land 2017, 6, 78. [CrossRef]

8. Badmos, B.K.; Agodzo, S.K.; Villamor, G.B.; Odai, S.N. An Approach for Simulating Soil Loss from an Agro-Ecosystem Using Multi-Agent Simulation: A Case Study for Semi-Arid Ghana. Land 2015, 4, 607-626. [CrossRef]

9. Kuok, K.; Mah, D.; Chiu, P. Evaluation of C and P Factors in Universal Soil Loss Equation on Trapping Sediment: Case Study of Santubong River. J. Water Resour. Prot. 2013, 5, 1149-1154. [CrossRef]

10. Panagos, P.; Borrelli, P.; Meusburger, K.; van der Zanden, E.H.; Poesen, J.; Alewell, C. Modelling the effect of support practices (P-factor) on the reduction of soil erosion by water at European scale. Environ. Sci. Policy 2015, 51, 23-34. [CrossRef]

11. Karydas, C.G.; Sekuloska, T.; Silleos, G.N. Quantification and site-specification of the support practice factor when mapping soil erosion risk associated with olive plantations in the Mediterranean island of Crete. Environ. Monit. Assess. 2009, 149, 19-28. [CrossRef] [PubMed] 
12. Tian, P.; Zhu, Z.; Yue, Q.; He, Y.; Zhang, Z.; Hao, F.; Guo, W.; Chen, L.; Liu, M. Soil erosion assessment by RUSLE with improved $P$ factor and its validation: Case study on mountainous and hilly areas of Hubei Province, China. Int. Soil Water Conserv. Res. 2021, 9, 433-444. [CrossRef]

13. Mittelstet, A.R.; Storm, D.E.; White, M.J. Using SWAT to enhance watershed-based plans to meet numeric water quality standards. Biol. Syst. Eng. Pap. Publ. 2016, 386, 5-21. [CrossRef]

14. Mittelstet, A.R.; Storm, D.E.; Fox, G.A. Testing of the modified streambank erosion and instream phosphorus routines for the SWAT model. J. Am. Water Resour. Assoc. 2017, 53, 101-114. [CrossRef]

15. Department of Irrigation and Drainage Malaysia-DID. Guideline for Erosion and Sediment Control in Malaysia; DID: Lumpur, Malaysia, 2010.

16. Fatemeh, H.; Safwan, M.; Karam, A.; Glory, O.E.; Ahmad, H.; Hazem, G.A.; Jesús, R.C. CMIP5 climate projections and RUSLEbased soil erosion assessment in the central part of Iran. Sci. Rep. 2021, 11, 7273.

17. Stefanos, S.; Vasileios, A.; Chrysoula, C.; Panagiotis, S. Assessing soil loss by water erosion in a typical Mediterranean ecosystem of Northern Greece under current and future rainfall erosivity. Water 2021, 13, 2002. [CrossRef]

18. Stefanidis, S.; Chatzichristaki, C.; Stefanidis, P. An ArcGIS toolbox for estimation and mapping soil erosion. J. Environ. Prot. Ecol. 2021, 22, 689-696.

19. AbdelRahman, M.A.E.; Natarajan, A.; Hegde, R.; Prakash, S.S. Assessment of land degradation using comprehensive geostatistical approach and remote sensing data in GIS-model builder. Egypt. J. Remote Sens. Space Sci. 2019, 22, 323-334. [CrossRef]

20. Panos, P.; Cristiano, B.; Mihaly, H.; Simone, S.; Francis, M.; Mariia, B.; Jean, P.; Pasquale, B. Projections of soil loss by water erosion in Europe by 2050. Environ. Sci. Policy 2021, 124, 380-392.

21. Department of Agriculture-DOA. Land-Use Activities 2015; Department of Agriculture Malaysia: Putrajaya Federal Territory, Malaysia, 2015.

22. Department of Survey and Mapping Malaysia-JUPEM. Digital Elevation Model 2020; JUPEM: Kuala Lumpur, Malaysia, 2020.

23. Google Earth. Cameron Highlands, Malaysia. Available online: https:/ / earth.google.com/web/@4.47212375,101.38014488,-8610 1.14525661a,162789.78635436d,35y,0h,0t,0r?utm_source=earth7\&utm_campaign=vine\&hl=en (accessed on 20 November 2021).

24. Department of Town and Country Planning Malaysia-PLANMalaysia. Land-Use Activities 2018; PLANMalaysia: Putrajaya Federal Territory, Malaysia, 2018.

25. Layfield, Erosion Management Factors 2009. Available online: https://www.layfieldgroup.com/Geosynthetics/Tech-Notes / Erosion-Mgmt-Factors.aspx (accessed on 11 November 2020).

26. Troeh, F.R.; Hobbs, J.A.; Donahue, R.L. Soil and Water Conservation: Productivity and Environment Protection; Prentice-Hall: Hoboken, NJ, USA, 1999.

27. ECTC. Guidelines for Rolled Erosion Control Products; Erosion Control Technology Council: St. Paul, MN, USA, 2003.

28. SCS. Urban Hydrology for Small Watersheds; Tech. Release No. 55; Soil Conservation Service, U.S.D.A.: Washington, DC, USA, 1986.

29. UNEP; RIVM; ISRIC. A Qualitative Assessment of Water Erosion Risk Using 1:5 M SOTER Data; An Application for Northern Argentina South-East Brazil and Uruguay; Report 96/04; ISRIC: Wageningen, The Netherlands, 1996.

30. Israelsen, C.E.; Clyde, C.G.; Fletcher, J.E.; Israelsen, E.K.; Haws, F.W.; Packer, P.E.; Farmer, E.E. Erosion control during highway construction. In Manual on Principles and Practices; National Cooperative Highway Research Program Report 221; Transportation Research Board, National Research Council: Washington, DC, USA, 1980.

31. Wischmeier, W.H.; Smith, D.D. Predicting Rainfall Erosion Losses-A Guide to Conservation Planning; Agricultural Handbook No. 537; USDA: Washington, DC, USA, 1978.

32. Kuenstler, W. C Factor: Cover-Management. 2009. Available online: www.techtransfer.osmre.gov/NTTMainSite/Library/ hbmanual/rusle/chapter5.pdf (accessed on 11 November 2020).

33. River Engineering and Urban Drainage Research Centre, Universiti Sains Malaysia-REDAC USM. Research of Preparation Erosion and Sediment Control Plan (ESCP) Guidelines for Logging and Plantation Agriculture in Malaysia; National Water Research Institute of Malaysia (NAHRIM): Kuala Lumpur, Malaysia, 2020.

34. Musgrave, G.W. The quantitative evaluation of factors in water erosion: A first approximation. J. Soil Water Conserv. 1947, 2,133-138. 